\title{
ÖNBIZALOM ÉS VISSZAJELZÉS
}

\author{
Nyéki Emőke
}

\begin{abstract}
Absztrakt: A XXI. század technikai és technológiai fejlődése új kihívások elé állítja a munkaerőpiac minden szereplőjét. A megváltozott igényeknek megfelelően a felsőoktatásnak olyan munkaerőpiaci kompetenciákat kell tudniuk fejleszteni, melyeket elvárnak a munkaadók, illetve amelyekkel értékesebbé és keresettebbé válnak végzős hallgatóik a hazai munkáltatók körében. Olyan készségekre van szüksége a XXI. századi munkavállalónak többek között, mint önállóság, felelősségvállalás, másokkal való eredményes együttmüködés - melyek fejlesztéséhez és elsajátításához nem új tantárgyak kialakítása szükséges, hanem a tantárgyak tanítása során új módszertani elemeket kell tudni alkalmazni.

A megváltozott elvárások és az új tanítás-módszertani elemek a hallgatók egészséges énképén és önértékelésén alapuló önbizalmát várják el, miközben a generációkutatók szerint az Y generáció önbizalma az, amelyet támogatni kell és érdemes. Kialakulhat-e egészséges önbizalom reális énkép nélkül? Mit tehet a felsőoktatás azért, hogy a hallgatók reálisan értékeljék meglévő képességeiket és tudatosan fejlesszék azokat a munkaeröpiaci elvárásoknak megfelelően?

A felsőoktatásban részt vevő hallgatóik körében végzett felmérés azon eredményei, melyek a hallgatók önbizalmára vonatkoztak, a versenyszféra felsővezetőinek körében végzett felmérési eredményekkel kerültek összehasonlításra. Hasonlóságokat és különbözőségeket vizsgálva a kutatás a felmerülő kérdésekre keresi a választ, melyekkel a hallgatóknak, a munkaadóknak és a felsőoktatásban dolgozóknak egyaránt segítséget kíván nyújtani napjaink kihívásai közepette.
\end{abstract}

Abstract: The technological and technological advances of the 20th century put new challenges on every members of the labor market. In line with the changed needs, higher education should be able to develop labor market competencies that employers expect and their graduates to become more valuable and more demanding among domestic employers. You need skills in the 21 st century for example, self-reliance, responsibility, effective cooperation with others - the development and acquisition of which do not require the development of new subjects, but also the use of new methodological elements in the teaching of subjects.

The changed expectations and new elements of teaching methodology expect the self-confidence of students based on their self-image and self-assessment, while generational researchers say that the self-confidence of the $\mathrm{Y}$ generation is what needs to be supported and worthwhile. Can healthy selfconfidence develop without a realistic self-image? What can higher education do to make students realistic about their existing skills and consciously develop them according to labor market expectations?

The results of the survey among students participating in higher education that relate to students' selfconfidence were compared with survey results from senior executives in the private sector. Analysing similarities and differences, research is looking for answers to emerging questions that will help students, employers, and higher education workers alike in the face of today's challenges.

Kulcsszavak: önbizalom, munkaerőpiaci elvárások, készségek, felsőoktatás, hallgatók, munkaadók

Keywords: self-confidence, labor market expectations, skills, higher education, students, employers

\section{Bevezetés}

A XXI. században olyan új technológiák alkalmazásával, mint a robotika vagy a 3D nyomtatás, ugrásszerű fejlődés tapasztalható az ipar számos területén. Az új technológiák új készségek elsajátítását teszik szükségessé a munkavállalók részéről. Ugyanakkor nem egyértelmüen meghatározható, hogy a következő évtizedekben 
mely munkakörökben lesz szükség emberi munkaeröre és melyeket váltanak ki részben vagy teljes egészében a technológiai fejlődés produktumai.

A felsőoktatásnak fel kell készítenie a jövő munkavállalóját a munkaerőpiacon való helytállásra, azonban nem megjósolható, hogy mely munkaköröket kell betöltenie munkavállalóként a ma egyetemi hallgatóként tanuló generációnak. A dilemma nem pusztán csak a high-tech iparágakban van jelen, hanem olyan korábban nagyszámú munkaerőt igénylő munkakörökben is, mint a szupermarketek vagy a bankfiókok pénztárosi munkakörei, ahol az élö munkaerőt vonalkód-leolvasó pénztárak vagy ATM-ek helyettesítik. Másrészről olyan, korábban szaktudást nem igénylő munkakörök, mint a takarító, mára szakképesítés nélkül ritkán betölthetők és a több milliós professzionális eszközök használatához nem pusztán szaktudás, de felelösségérzet és megbízhatóság is szükséges.

A World Economic Forum 2018-as jelentésében, melyben 20 fejlett és fejlődő országból - melyek együttesen a globális GDP 70\%-át képviselik - 313 válaszadó több, mint 15 millió munkavállalóra vonatkozó válaszai alapján kerültek elemzésre a munkakörök várható alakulása. Bizonyos munkahelyek 10\%-os strukturális csökkenését becsülték meg a válaszadók, új munkahelyek és új szakmák 11\%-ban jelennek meg, míg a legfontosabb munkahelyek - a foglalkoztatás nagy részét kitevő iparágakban - továbbra is stabil marad a jelentés szerint. ${ }^{1}$

A válaszadók feleslegessé váló munkahelyként prognosztizálják a jövőre nézve az adatrögzítő, a vezetői asszisztens, a bankpénztáros, a postahivatali ügyintéző, az autó-, teherautó- és motorvezető, a telemarketinges, de még a jogász munkahelyeket is. (World Economic Forum - The Future of Jobs Report 2018:21) A válaszadók egyszerre tekintik stabilnak és megszünőnek az ügyvezetői pozíciót - a feladatok egy része feltételezhetően átalakul, a pozíció valószínüleg nem szünik meg, de más lesz a vezető hozzáadott értéke a szervezet müködéséhez. Ugyanez igaz az ügyfélszolgálatos munkakörre - a chatbot-ok elterjedésével már napjainkban is érezhető a call centerek és telefonos ügyfélszolgálatok müködésének változása.

Mivel az egyes szakmák és munkahelyek jövője nem megjósolható, akár ugyanarról a munkakörről különböző munkáltatók máshogy vélekednek a jövőre vonatkozóan, a jövőben szükséges tudás és készség meghatározása nem könnyü. Az OECD az általa meghatározott kulcskompetenciákat három kategóriába sorolja²: teljesítéssel kapcsolatos kompetenciák, interperszonális kompetenciák és stratégiai, a jövő tervezéséhez kapcsolatos kompetenciák csoportját képezve. A teljesítéssel kapcsolatos kompetenciák között szerepel az analitikus gondolkodás, a teljesítményfókusz, a megfogalmazás képessége, a rugalmas gondolkodás, az erőforrás menedzsment, a csoportmunka és a csapatok vezetése. Az interperszonális kompetenciák közé sorolja az OECD az ügyfélfókuszt, a másokkal való együttműködés során tanúsított diplomáciai érzékenységet, a befolyásolás képességét, a nyer-nyer együttmüködést eredményező egyeztetési készséget és a

\footnotetext{
${ }^{1}$ World Economic Forum - The Future of Jobs Report 2018 (2018) Internetes forrás. Online: http://www3.weforum.org/docs/WEF_Future_of_Jobs_2018.pdf Letöltés: 2019. 03.23.

${ }^{2}$ Competency Framework OECD (2014) Internetes forrás Online:

https://www.oecd.org/careers/competency_framework_en.pdf Letöltés: 2019. 03.23.
} 
szervezeti tudást, amely magába foglalja a saját és más szervezetek ismeretét, amely képessé teszi az egyént olyan döntések meghozatalára, melyet mások elfogadnak és követnek. A stratégiai készségek között szerepel a tehetség fejlesztése, a szervezeti célok összehangolása az egyéni célokkal és szükségletekkel, a stratégiai kapcsolatépítés, és a stratégai gondolkodás.

Ugyanakkor az OECD-n kívül több szervezet definiálja a munkaeröpiacon szükséges kompetenciákat és ezek nem minden esetben fedik egymást. Számtalan magyar, európai és USA-beli szervezet definiál munkaerőpiaci kompetencialistát. A munkaadók által meghatározott kulcskompetenciákat végiggondolva felmerül a kérdés, hogy a felsőoktatás hogyan képes felkészíteni a jövő munkavállalóit a munkaerőpiac által elvárt kulcskompetenciák fejlesztésével. A szakmai tudáson kívül olyan globálisan fontosnak tartott kompetenciák lesznek szükségesek a munka világában, amelyeket az automatizálás nem képes pótolni és csak az élő munkaerő lesz képes produkálni a munkaerőpiacon.

A 2003-ban megjelent OECD tanulmány arra keresi a választ, hogy az emberek hol és hogyan szeretnek leginkább tanulni. ${ }^{3}$ Tanulási stílusokra nem talál egységes és használható iránymutatást, azonban abból a tényből indul ki, hogy sikeres tanulás akkor valószínü, ha a tanuló nagyfokú önbizalommal és megfelelö önbecsüléssel rendelkezik, erősen motivált a tanulásra és tanulási környezetét „nagyfokú kihívás” és ,alacsony fenyegetettség” jellemzi.

Ugyanakkor a tanulmány szerint a tanulók számára jelentkező elsődleges problémát az alacsony önbizalom és a motiváció hiánya jelenti. Az önbizalom és az önbecsülés szükséges, de nem elégséges feltétele a motivációnak (az igazán tanulni akarásnak).

Jelen tanulmány arra kérdésre keresi a választ, hogy a felsőoktatásban tanuló hallgatók a munkaerőpiac által meghatározott kompetenciák közül melyeket tartja fontosnak és ezek megegyeznek-e a munkaerőpiac elvárásaival, illetve milyen tanulásmódszertani megoldásokkal kívánják elsajátítani azokat a hallgatók. A felmérés eredménye a felsőoktatás eredményességéhez kíván hozzájárulni, rámutatva arra, hogyan és miben kell fejleszteni a jövő munkavállalóit, inspirálva és motiválva a hallgatókat a fejlődésre, erősítve az önbecsülésüket és az önbizalmukat.

\section{Anyag és módszer (például)}

A tanulmány egy jelenleg folyó, 2019. március 17-én elindított felsőoktatásban tanuló hallgatók körében elindított felmérés már meglévő eredményeit vizsgálja. A felmérés időszakában Magyarországon felsőoktatási tanulmányokat folytató hallgatók válaszai alapján vizsgálja a felmérés a hallgatók által legfontosabbnak ítélt munkaerőpiaci kompetenciákat, melyekkel egy pályakezdőnek rendelkeznie kell, illetve hogy milyen kompetenciáikat szeretnék fejleszteni és milyen módszertanokat preferálnak a válaszadók az oktatás során. A hallgatók által fontosnak tartott

\footnotetext{
${ }^{3}$ Az agy megértése: útban egy új tanulástudomány felé OECD 2003:12
} 
munkaerőpiaci kompetenciákat veti össze a magyarországi munkaadók által megnevezett elvárt kompetenciákkal.

“A fiatalok vagy felnőttek oktatásának gyakorlati felelősségének terén nyert tapasztalat a motiváció, az önbizalom és a siker jó példájának mindennél nagyobb fontosságát hangsúlyozza." (Az agy megértése: útban egy új tanulástudomány felé OECD 2003:2)

A felmérés vizsgálja a hallgatók saját magukról alkotott képét és az abból eredő önbizalmat, mely az új ismeretek elsajátítására való motiváció kulcsa. A múltbeli tanulási sikerélmény inspirálja a tanulót új ismeretek megszerzésére. A kérdőíves felmérés válaszait elemzi a tanulmány arra vonatkozóan, hogy a fontosnak tartott kompetenciákat milyen módszerrel szeretnék fejleszteni, milyen tanulási módszertannal tanulnak szívesen.

Tanulás-módszertani szempontból kiemelkedő jelentőségű az érdemjegyeken kívüli visszajelzés az oktatóktól. Ezért a kérdőív vizsgálja a hallgatók tanulmányai során kapott visszajelzéseket és összeveti annak eredményét egy korábbi pilot felmérés eredményével. A 2018-ban végzett pilot felmérésben a hallgatók saját képességeiket és eredményeiket értékelték, mint önbizalmuk kulcstényezöit. A hallgatói válaszokat a versenyszférában dolgozó első számú vezetők önértékelésével veti össze - keresve a hasonlóságokat és eltéréseket.

A tanulmány tehát a kérdőíves felmérések eredményeiből a hallgatók motivációját emeli ki az elsajátítani kívánt kompetenciákra vonatkozóan, összehasonlítva a munkaerőpiac elvárásaival, keresve a választ arra a kérdésre, hogy a hallgatók tisztában vannak-e a velük szemben támasztott elvárásokkal. Mindezeken kívül kiemeli azokat a tanulásmódszertani megoldásokat, amelyekkel a hallgatók szívesen sajátítják el a szükséges tudást.

Az adatgyüjtés magyarországi felsőoktatási intézmények különböző tanszékeire való eljuttatásával, illetve a hallgatók közvetlen elérésével történt online közösségi oldalakon keresztül. Az adatgyüjtés rögzített kérdésekkel történt, a komparatív elemzés érdekében választható válaszokkal, egyszeri vagy többszörös választási lehetőséggel. A válaszadók véleménye értékelőskálán 1-5-ig megadott értékek illetve igen/nem válasz megadásával került gyüjtésre az egyes kérdések esetén. A rangsorolás meghatározására értékelőskála került alkalmazásra. A válaszok értékelése matematikai statisztikai módszerekkel történt, átlag és szórás értékek számításával.

A felmérés az elérni kívánt reprezentatív minta számát 300 kitöltőben határozta meg, melyből a tanulmány készítésekor 165 válasz áll rendelkezésre. A 21 felsőoktatási intézményből érkező válaszok mennyisége és összetétele kellő számúnak tekinthető az értékeléshez és a tanulmány elkészítéséhez, azonban a felmérési felület továbbra is nyitva áll a célként megjelölt 300 kitöltő eléréséig.

\section{Eredmények és értékelésük}

A tanulmányban 21 magyarországi felsőoktatási intézményben tanuló 165 válaszadó válaszai kerülnek elemzésre. A bevezető kérdések között szerepel, hogy a kitöltő bízik-e abban, hogy az oktatási intézmény, ahol tanul, felkészíti a munka világában 
való helytállásra? A válaszadók 73\%-a igen-nel válaszolt a kérdésre, azonban 27\%uk a nem választ jelölte be a kérdésre. A válaszok megoszlását az 1 . sz. ábra szemlélteti.

\section{1. ábra: Bizalom az oktatási intézményben}

\section{Bízik-e abban, hogy az oktatási intézmény, ahol tanul, felkészíti a munka világában való helytállásra?}

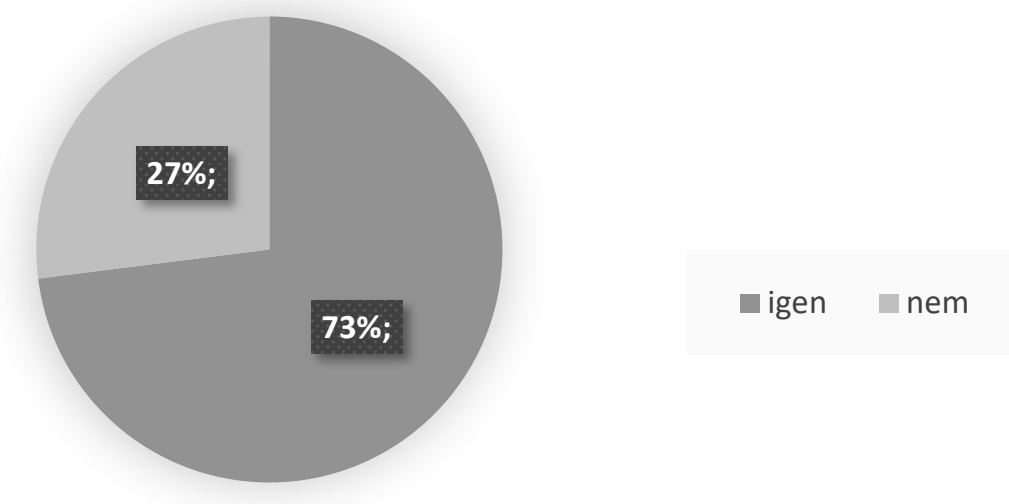

Forrás: A szerző saját szerkesztése.

A kérdöív arra a kérdésre, hogy $A z$ Ön megítélése szerint az Ön felsöoktatásban tanult szakmájában milyen készségekre és kompetenciákra van leginkább szüksége hazájában egy pályakezdönek? a magyarországi munkáltatók által elvárt 13 kompetencián kívül felsorol még 8 olyan kompetenciát, amelyeket a nem magyarországi szervezetek (UK, USA, EU, UNESCO) határoztak meg. Egy olyan kompetencia is bekerült a felsorolásba, melyet egyetlen szervezet sem nevezett meg, ez a „helyzetelemzés”. A magyarországi és a külföldi szervezetek által fontosnak tartott kompetenciák vegyesen kerültek felsorolásra és közéjük került az az egy kompetencia is, amelyet egyik szervezet sem jelölt. A kérdőív szerkesztésekor az volt a feltételezés, hogy a 22 felsorolás hosszú, a kompetenciák kiválasztásakor az felsorolás elején lévőket gyakrabban választják az 5 legfontosabb kompetencia kiválasztásakor a kitöltők. Ez a feltételezés bizonyos mértékben igazolódott, bár a felsorolásban az utolsó kompetenciákat is többen választották, mint a legkevesebbszer megjelölt kompetenciát. A „helyzetelemzés”-t - bár az első öt választható kompetencia közé került a felsorolásban - a válaszadók az első 8 választható válasz közül a legkevesebbszer jelölték, mely alapján feltételezhető, hogy a válaszok megjelölésekor valódi mérlegelés történt. A 2. sz. ábra a válaszok megoszlását mutatja, a kérdőívben szereplő felsorolás sorrendjében balról jobbra láthatóak a kompetenciák. 
2. ábra: Pályakezdőkkel szembeni kompetencia-elvárások Magyarországon a felsőoktatási hallgatók megítélése szerint

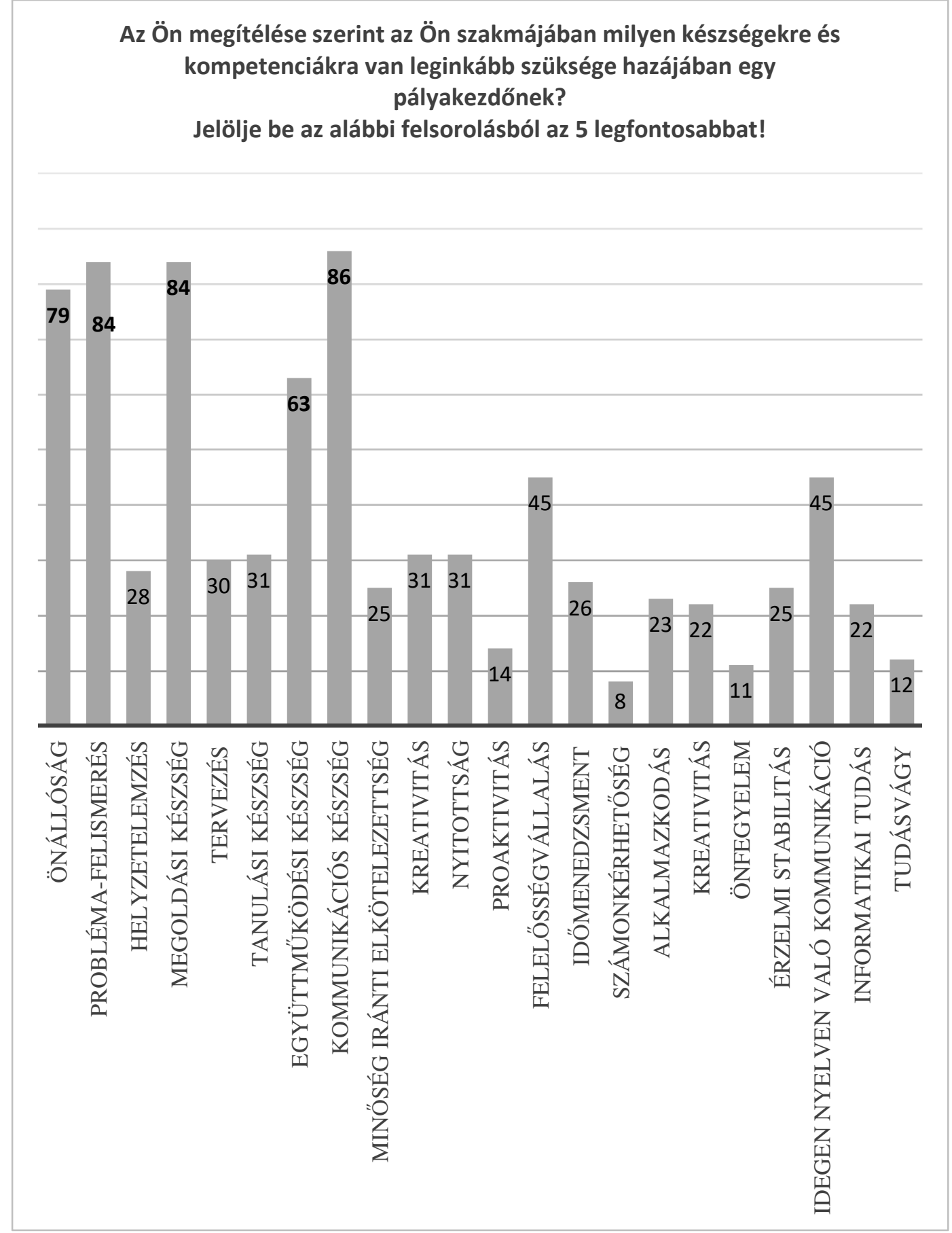

Forrás: A szerző saját szerkesztése.

A kitöltők a 22 felsorolt kompetenciából az általuk 5 legfontosabbnak ítéltet kellett, hogy megjelöljék. A felmérés eredményeként a hallgatók a kommunikációs készséget, a megoldási készséget, a probléma-felismerést, az önállóságot és az 
együttmüködési készséget ítélték a legfontosabbnak - utóbbit tizenhattal kevesebbszer jelölték, mint a negyedik legtöbbször jelölt önállóságot. A leggyakrabban jelölt öt válasz közül tehát négy intraperszonális és csak egy interperszonális készséget jelöltek a válaszadók, mint leginkább szükséges készséget, miközben a munka világában kiemelt elvárás a másokkal való eredményes együttmüködés. Ugyanakkor másokkal az képes eredményesen együttmüködni, aki önmaga is eredményes - így a hallgatók fókusza a saját müködésükre lehet a fejlödési folyamatuk fontos állomása, azonban a tanulási környezetet úgy kell a felsőoktatásnak alakítania, hogy minél többször legyen lehetőségük interperszonális képességeik gyakorlására. A legfontosabbnak ítélt kommunikációs készséget, a megoldási készséget és a probléma-felismerést 86-8484-en jelölték. A hallgatók által legfontosabbnak ítélt kompetenciák mindegyikét a magyarországi munkáltatók köréből származó kompetencialista is tartalmazza, a hallgatók - válaszaik alapján - tisztában vannak a magyarországi munkáltatók velük szemben támasztott elvárásaival.

A kérdőív kitöltése során a hallgatóknak a 8 alapkompetencia közül - melyet az Európa Tanács 2002-ben fogadott el az egész életen át tartó tanulás során elsajátítandó új alapkészségek európai referenciakereteként - azokat kellett megjelölnie, amelyeket tanulmányaik során szeretnék fejleszteni. A megjelölhető kompetenciáknak nem volt minimuma és maximuma sem. A 165 válaszadó összesen 528 kompetenciát jelölt meg, átlagosan 3,2 kompetencia fejlesztését célként megjelölve. A válaszok alapján a hallgatók tisztában vannak az idegen nyelv fontosságával, az idegen nyelvi kommunikációt 124-en jelölték meg, míg a második leggyakrabban jelölt vállalkozói kompetenciát 82-en, a harmadik helyen a digitális kompetencia áll 68 jelöléssel. A magyarországi munkaadók a mérnökökkel szemben elvárt kompetenciák között megjelölte az idegen nyelv ismeretét, kiemelten az angol nyelvet, és az EU-n belül is elvárás az anyanyelven kívüli idegen nyelv ismerete. A világnyelvet beszélő országokban az idegen nyelv ismerete nem elvárás érthető módon, azonban hazánkban az idegen nyelv hiánya jelentősen leszúkíti a munkahelykeresés esélyeit, függetlenül a tanult ismeretektől és végzettségtől. A további részleteket a 3. sz. ábra tartalmazza. 
3. ábra: Hallgatók szándéka szerinti saját fejlesztendő kompetenciák

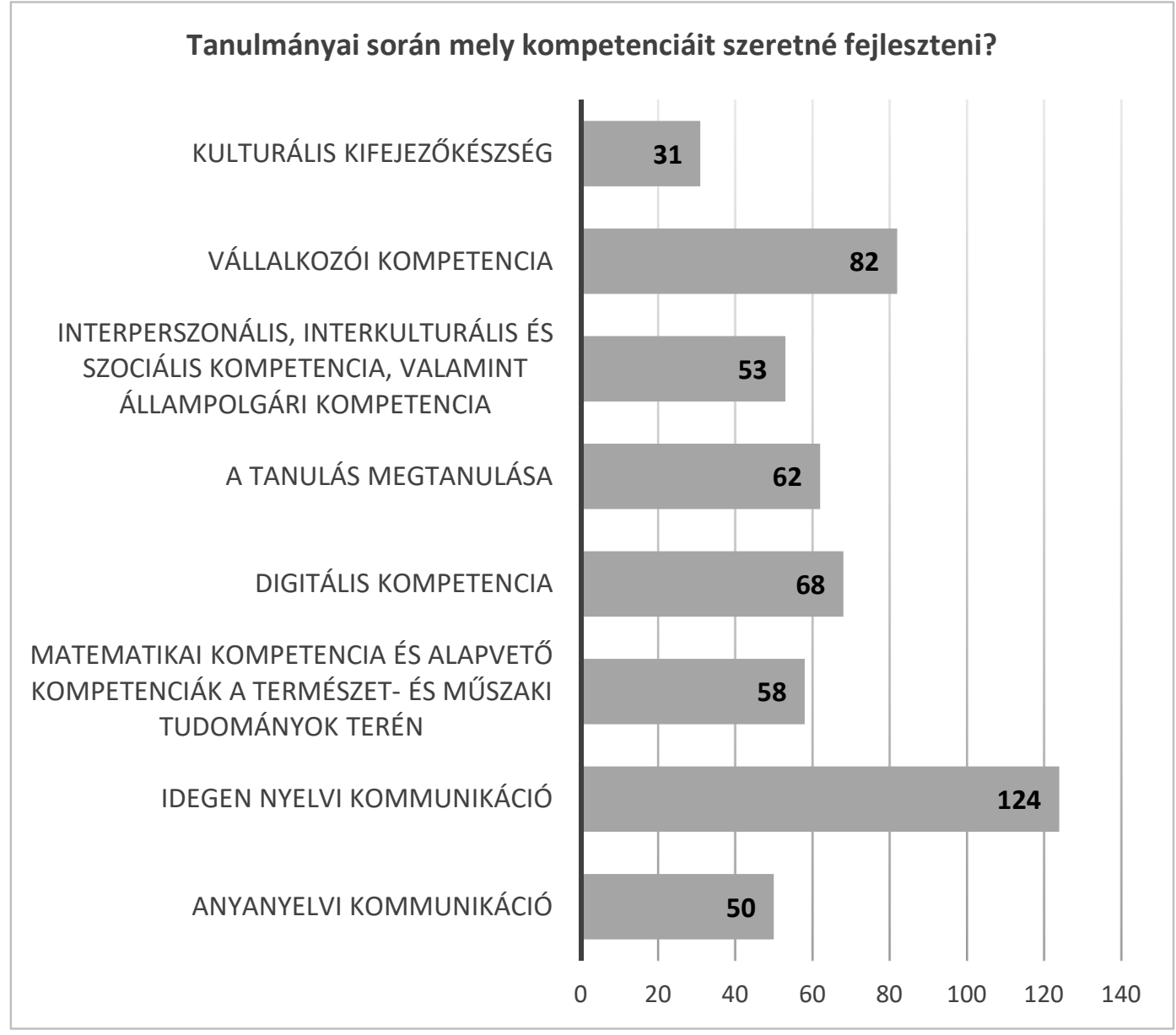

Forrás: A szerző saját szerkesztése.

A kérdőív utolsó, jelen tanulmányban vizsgált kérdése arra vonatkozott, hogy elöfordult-e, hogy a kitöltő érdemjegyeimen kívül kapott visszajelzést (akár informálisan is) meglévő készségeire oktatóitól? A 165 válaszadóból 96-an Igen-nel válaszoltak a kérdésre, míg 69-en Nem-mel. Az eredmény értékelése a megoszlás szempontjából pozitív, hiszen többen kaptak visszajelzést készségeikre, mint nem, azonban a 165 válaszadó 42\%-a nem-mel felelt. A tanulási készség fejlesztése szempontjából azonban kiemelt fontosságú a meglévő készségekre való visszajelzés, amely a hallgató énképét és önértékelését erősíti. A válaszok megoszlását az 4. sz. ábra mutatja. 


\section{4. ábra: Oktatói visszajelzés gyakorisága}

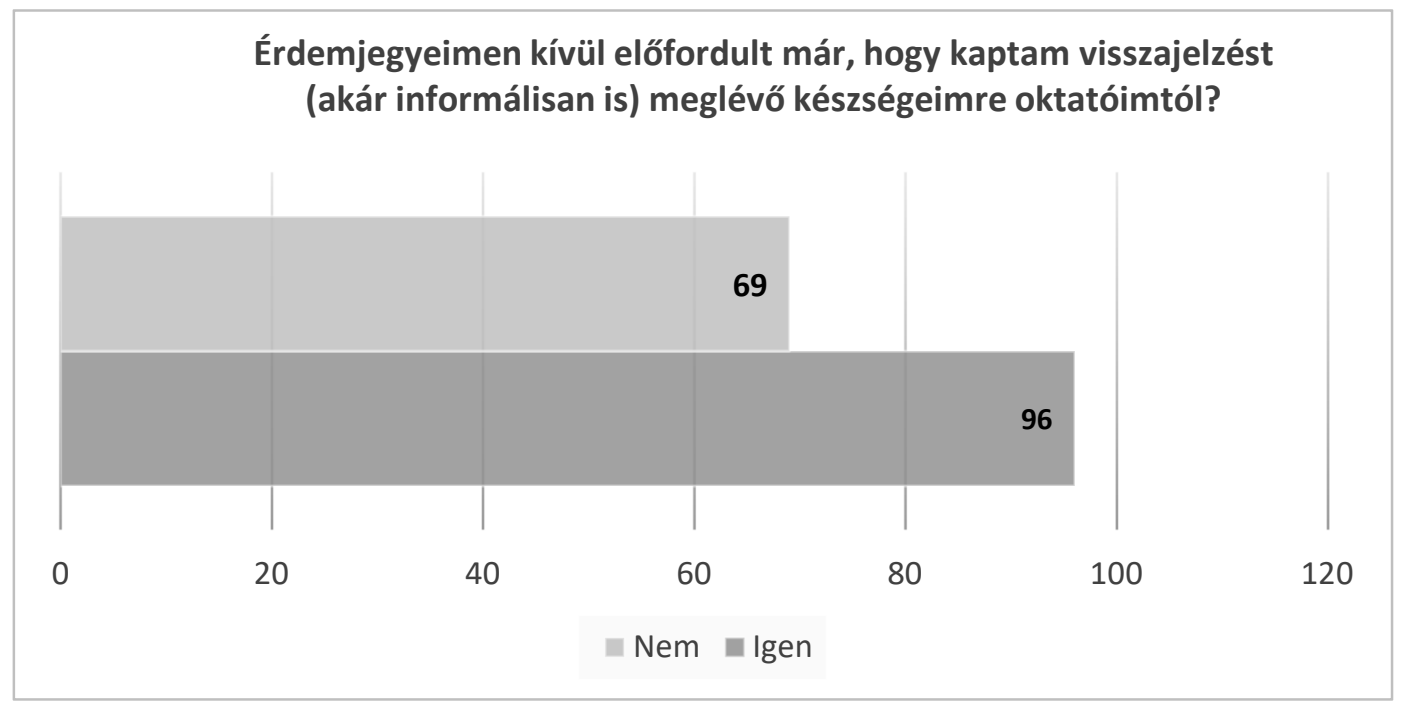

Forrás: A szerző saját szerkesztése.

A visszajelzés nem pusztán a tanulási készség fejlesztése szempontjából fontos. A hallgatók önértékelését fejleszti a visszajelzés, segíti a reális énkép kialakítását. Ez a munkaerőpiac aktív szereplöire nézve is igaz, akár felsővezetői körben is, sőt egyes generációs felmérések szerint az Y generáció hetente igényli a vezetői visszajelzést.

Egy korábbi pilot felmérésben 11 első számú vezető (CEO) és az ő 84 közvetlen beosztottjaik, akik szintén vezető beosztásban vannak (Management) értékelték saját képességeiket és eredményeiket. Ugyanazokra a kérdésekre válaszoltak a 2018/2019-es öszi és tavaszi félévében a BME mérnök hallgatói 20-an, illetve 14en. 
5. ábra: Önértékelés - képességek és eredmények (saját pilot kutatás)

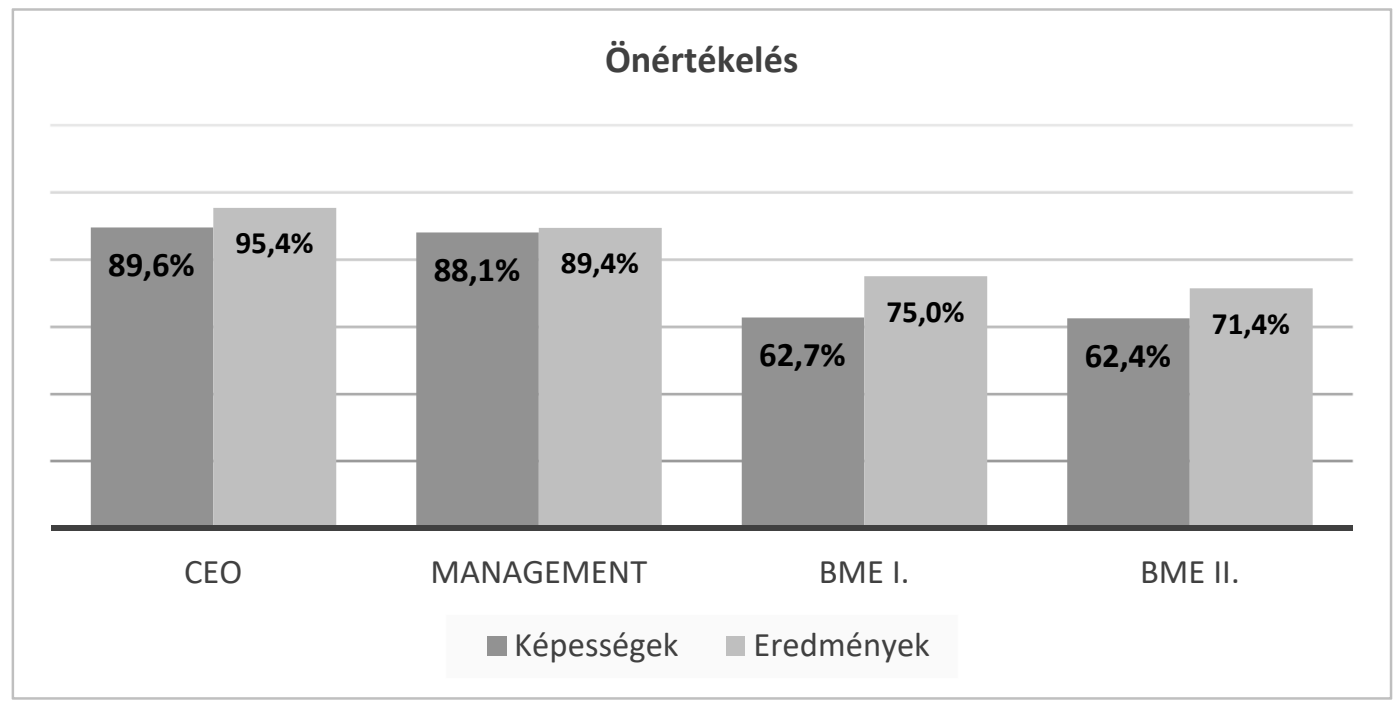

Forrás: A szerző saját szerkesztése.

Az 5. sz. ábrán jól látszik az azonos tendencia: az üzleti élet szereplői és a felsőoktatásban tanuló hallgatók egyaránt magasabbra értékelték az eredményeiket, mint képességeiket. Az értékelés 1-10-es skálán történt és az üzleti szféra szereplöi érthető módon magasabb értékeket adtak önértékelésük során, mint a hallgatók. Az eredményekre vonatkozóan minden hallgató rendszeres visszajelzést kap tanulmányai során a ZH és vizsgaeredmények vonatkozásában, amelyek számszerü, objektív visszajelzések. Ugyanez igaz az üzleti életben a vezetőkre, a célszámok és a tényszámok napi szinten objektív adatként állnak rendelkezésre a vezetők saját eredményeinek értékeléséhez. Azonban a készségeink megítélése szubjektív, azokat gyakran önkritikusan értelmezzük. A 6 . sz. ábra mutatja a jelenleg folyó felmérésben a 165 felsőoktatási hallgató válaszát a saját tanulmányi eredményük megítélésére vonatkozóan. 1-5-ös skálán a válaszadók 30,67\%-a 5-re értékelte elégedettségét - ugyanakkor 8,59\%-uk 1-re. Felsőoktatási hallgatókkal folytatott személyes beszélgetések során a hallgatók többször említették, hogy vizsgaidőszakban számukra megtanulhatatlan mennyiségü tudásanyagot kell elsajátítaniuk, ezért sok esetben még egy jó érdemjegy sem ad reális visszajelzést képességeikről és valódi tudásukról. Időnként jó eredményüket a szerencsének tulajdonítják, ha a vizsgakérdések éppen arra a tudásanyagra kérdez rá, amelyet sikerült elsajátítaniuk. 
6. ábra: Hallgatók saját tanulmányi eredményének önértékelése

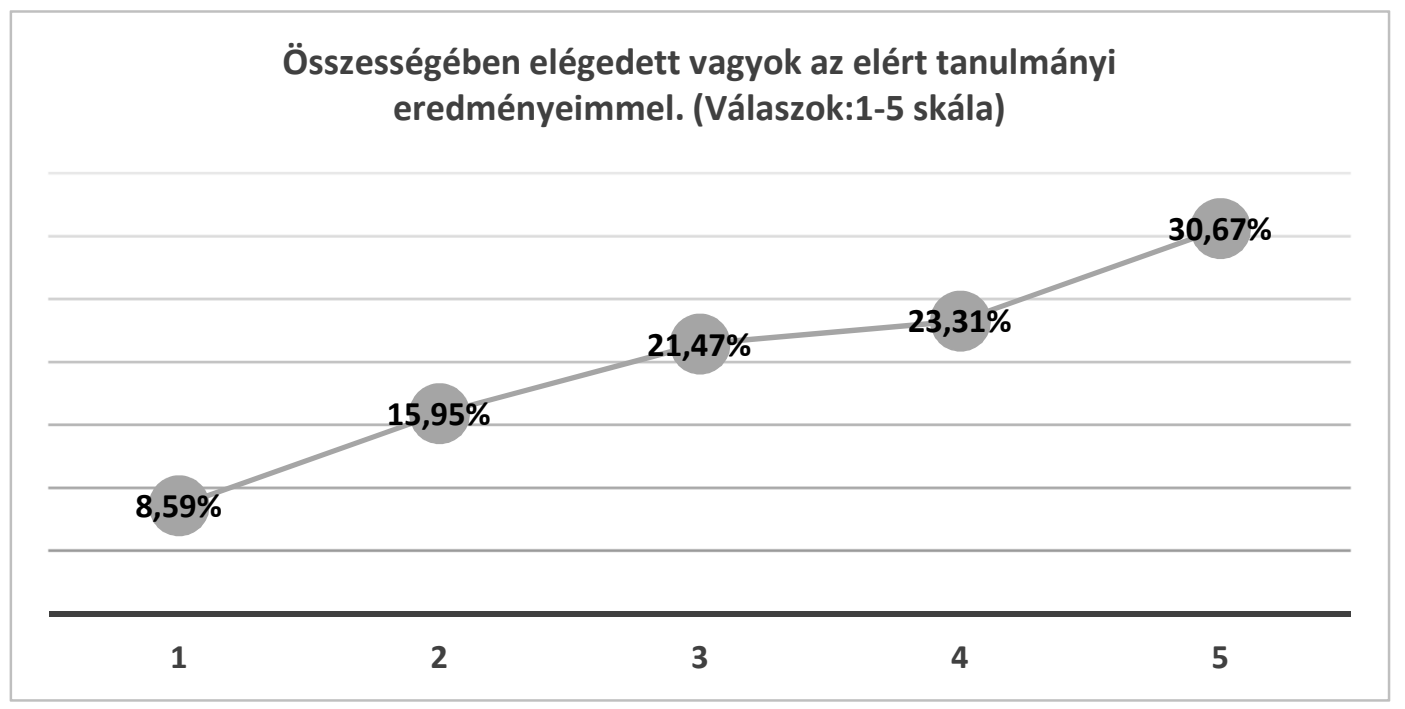

Forrás: A szerző saját szerkesztése.

\section{Következtetések, összegzés, záró megjegyzések, záró gondolatok}

A XXI. század technikai-technológiai fejlődés újfajta munkaerőpiaci elvárásokat támaszt a munkavállalókkal szemben, melyre az oktatási rendszernek fel kell készítenie a tanulókat. Az elvárások a technológiai és gazdasági környezet változásával együtt folyamatosan változik, amit a képzési rendszer nem képes olyan gyorsan lereagálni, amilyen gyorsan keletkeznek az új elvárások a munkaadók részéröl. A képzési rendszer akkor tekinthető eredményesnek, ha a változásra is képes felkészíteni a képzésben részt vevőket, nem pusztán az átadott tudást frissíti az elvárásoknak megfelelően. Ehhez az önálló tanulás készségét kell fejleszteni a tanulókban. Az önálló tanulásra való képesség pedig a meglévő tudás és képesség megerősítésével fejleszthető. Míg a hibák kijavítása és annak hangsúlyozása az egot veszélyezteti, a bizonytalanság nagyobb mértékủ tolerálását javasolja Lyman (1997) és Bolhuis), valamint a kockázat vállalására kell buzdítani a tanulót. (Kálmán 2009) A tanulási folyamatban a tanulók erősségeit kell kihasználni a gyengeségekre és hibákra való koncentrálás helyett, mert ezzel erősíti a tanár a motivációt és az önálló tanulásra való képességet. ${ }^{4}$

Ahogyan a tanulmány alapjául szolgáló felmérés is bizonyítja, a felsőoktatási hallgatók nagyobb mértékben bíznak a felsőoktatási intézményben, hogy képes felkészíteni őket a munkaerőpiac elvárásainak való megfelelésben, azonban a válaszadó $27 \%$-a nincs erről meggyőződve. A hallgatók többsége tisztában van azzal, hogy mely munkaeröpiaci kompetenciákban kell fejlődniük és azokban akarnak is fejlődni, de ahhoz, hogy képesek legyenek önmagukban bízni és valós, meglévő képességeikre tudatosan támaszkodjanak a tanulás során, formális és

\footnotetext{
4 Dr. Kálmán Anikó: Az oktatástól az önálló tanulásig - Budapesti Műszaki és Gazdaságtudományi Egyetem Alkalmazott Pedagógia és Pszichológia Intézet Müszaki Pedagógia Tanszék - Budapest 2009:20
} 
informális módon egyaránt kell, hogy kapjanak visszajelzést tanáraiktól meglévő képességeikre. Így válhat a tanulási környezet inspirálóvá ugyanakkor kevésbé fenyegetővé, mely a hivatkozott OECD tanulmány szerint a sikeres tanulási környezet ismérve. A hallgatók valós ismereteken és önismereten alapuló önbizalma nő a megerősítő visszajelzések hatására, amely növeli a tanulásban való motivációt. Az oktató pozitív meggyőződése, bizalma, ha találkozik a tanuló önmagáról alkotott pozitív meggyőződésével, akkor kialakul a hallgató és az oktató közötti bizalom, amely hatással van az oktatási rendszerben való bizalom mértékére is. A bizalom ilyen módon stabilizálja, megerősíti a tanuló és az oktató, illetve a tanuló és az intézmény kapcsolatát, képessé válnak a jövőre vonatkozóan együttmüködésük eredményességében. ${ }^{5}$ A hallgatók pedig kikerülve a munkaerőpiacra, jól képzett szakemberekként tudásukkal és készségeikkel érdemessé válnak munkatársaik, vezetöik és a társadalom bizalmára. (Giddens 1990$)^{6}$

\section{Irodalomjegyzék}

Az agy megértése: útban egy új tanulástudomány felé OECD 2003

Competency Framework OECD (2014) Internetes forrás Online: https://www.oecd.org/careers/competency_framework_en.pdf Letöltés: 2019. 03.23.

Giddens, A. (1990), The Consequences of Modernity. Stanford, CA: Stanford University Press

Dr. Kálmán Anikó: Az oktatástól az önálló tanulásig - Budapesti Müszaki és Gazdaságtudományi Egyetem Alkalmazott Pedagógia és Pszichológia Intézet Mủszaki Pedagógia Tanszék - Budapest 2009

Reinhard Bachmann és Akbar Zaheer: Handbook of Trust Research - 2006

The Future of Jobs Report 2018 - World Economic Forum - (2018) Internetes forrás. Online: http://www3.weforum.org/docs/WEF_Future_of_Jobs_2018.pdf Letöltés: 2019. 03.23

\footnotetext{
${ }^{5}$ Richard Arena, Nathalie Lazaric and Edward Lorenz: Trust, codification and epistemic communities: implementing an expert system in the French steel industry - Handbook of Trust Research -Reinhard Bachmann és Akbar Zaheer 2006:204

${ }^{6}$ Giddens, A. (1990), The Consequences of Modernity. Stanford, CA: Stanford University Press.
} 